
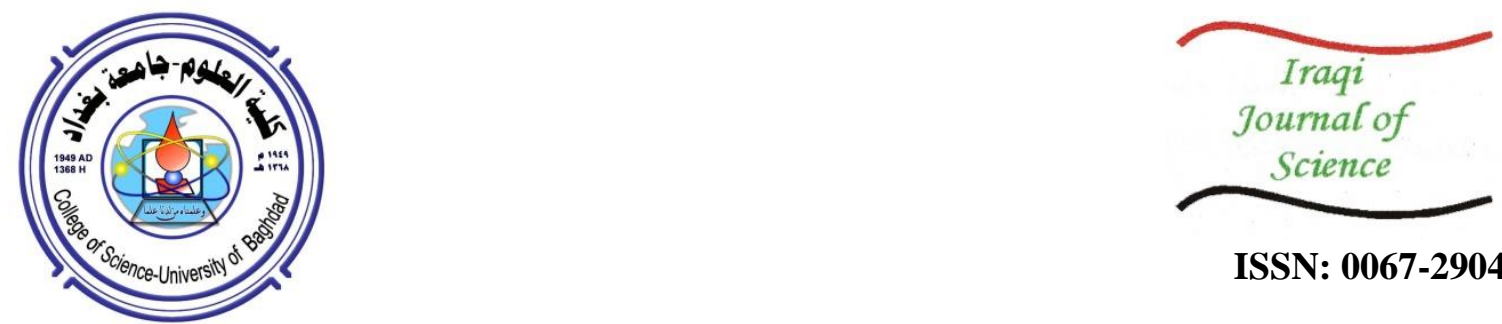

ISSN: 0067-2904

\title{
Structural and Rock Slope Stability Assessment of Some Sites Along Sirwan Road, Sulaimaniyah Governorate, Northeast Iraq
}

\author{
Omar Gheni Aziz ${ }^{1}$, , Thair Thamer Al-Samarrai ${ }^{1}$, Salim Hassan Al-Hakari ${ }^{2}$ \\ ${ }^{1}$ Department of Geology, College of Science, University of Baghdad, Baghdad, Iraq \\ ${ }^{2}$ Department of Geology, College of Science, University of Sulaimaniya, Sulaimaniya, Iraq
}

\begin{abstract}
A structural and engineering geological study of rock slope stability was carried out in six stations that lie in the Southwest of Baranan mountain, along Sirwan road. The rock slopes and discontinuities were surveyed at each of these stations, and the relationships with failures were determined. The slopes were classified on the basis of (Al-Saadi, 1981), and the rocks were described in engineering terms according to (Anon, 1972) and (Hawkins, 1986), Stereographic projection was made using software (GEOrient 9.5.0) to represent the field data that were recorded in order to understand the situation in the six stations (sites) that were chosen along Sirwan road near Darbandikhan dam, the failures' types were recorded during field study were rock fall, toppling, and sliding. The study also revealed that the factors affecting slope stability in the study area were slope angle, height, dip of strata, and discontinuities. The laboratory test of the rock samples (point-load test) showed that the average value of compressive strength of the rock for the study area is about 181.29 MPa.

Some measures are proposed to stabilize the slopes in the mentioned stations including; the removal of blocks liable to toppling in the critical cases (sites 2 and 6), casing the slopes with covenant materials such as concrete (site 4) and gabions (sites 2 and 6), with construction of retaining walls and digging of protective trenches to protect the slopes and reduce their hazard on the road (site 1,3, and 5).
\end{abstract}

Keywords: Slope Stability, Point Load Test, Stereographic projection, Sirwan road.

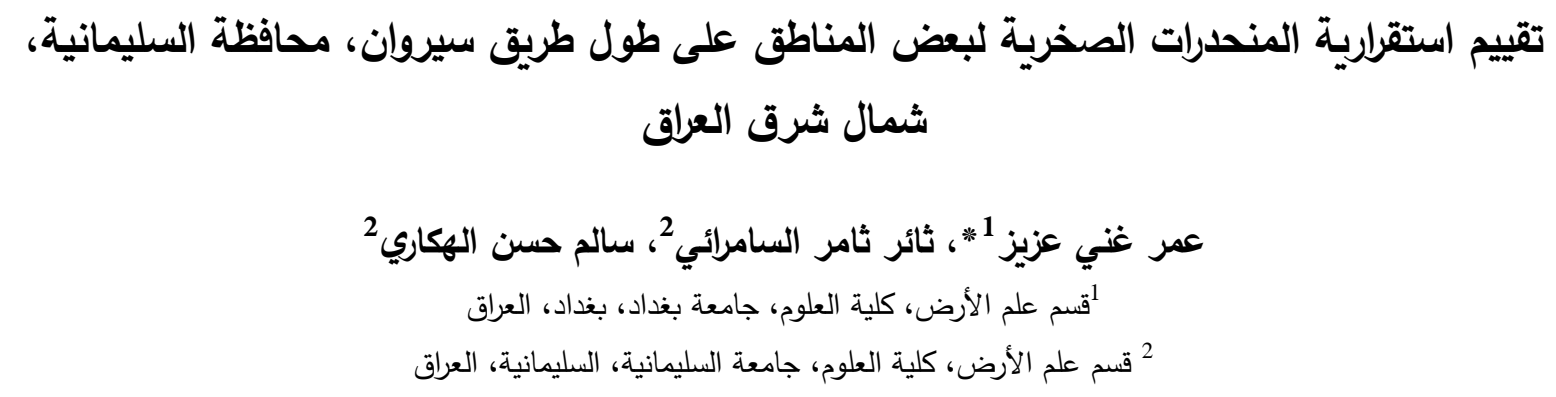

$$
\begin{aligned}
& \text { الخلاصة } \\
& \text { تم عمل دراسة جيولوجية تركيبية وهندسية لاستقرارية المنحدرات الصخرية لستة محطات تقع في الجنوب } \\
& \text { الغربي لجبل برنان، على طريق سيروان، وقد تم مسح المنحدرات الصخرية والانقطاعات في هذه المحطات، }
\end{aligned}
$$

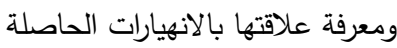

$$
\begin{aligned}
& \text { تم تصنيف المنحدرات وفقاً لتصنيف (Al-Saadi, 1981)، كما تم وصف الصخور وصفاً هندسياً وفقاً لـ (An) كمار } \\
& \text { (Hawkins, 1986) و (Hanon, 1972)، كما تم عمل الإسقاط المجسم باستخدام برنامج ( GEOrient) }
\end{aligned}
$$




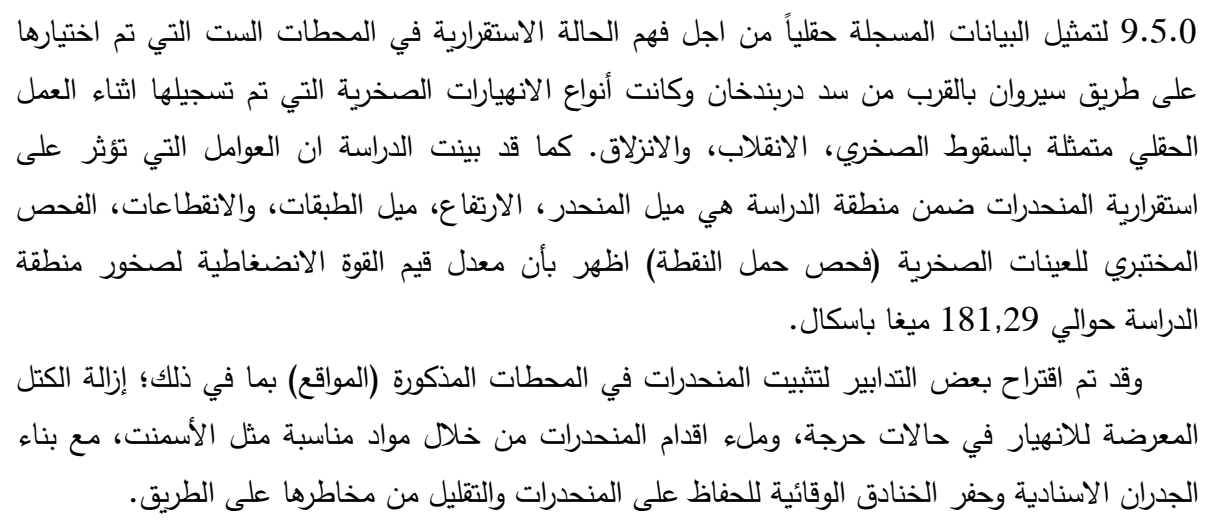

\section{Introduction}

The failure of rock slopes represents the movement of rock masses of various sizes downslope under their own weights involving positions changes of the rock masses horizontally, vertically, and obliquely. [1]

The rock mass strength, usually, keeps the slope at stable state. But, from time to time something happened that disturb the rock mass causing failure and downslope movement of the mentioned rock mass. [2]

This study aims to evaluate the stability of rock slopes in the study area through choosing 6 sites (stations) in which rock failure was occurred or is expected to occur in the future, the slopes were classified according to [3], and were analyzed by stereographic projection; using (GEOrient 9.5.0.) software, and rock masses were described in engineering geological terms according to [4] and [5].

\section{Location of the study area:}

The studied area lies along Sirwan road (for about $1.25 \mathrm{Km}$ length) covering area of about (2.2 $\mathrm{Km}^{2}$ ), between latitudes ( $\left.35^{\circ} 06^{\prime} 07^{\prime \prime}-35^{\circ} 06^{\prime} 40^{\prime \prime}\right)$ and longitudes $\left(45^{\circ} 41^{\prime} 49^{\prime \prime}-45^{\circ} 42^{\prime} 03^{\prime \prime}\right)$, and is located at about $(52 \mathrm{Km})$ to the southeast of Sulaimaniyah city, and about $(100 \mathrm{~m})$ to the west of Sirwan (Diyala) River, as shown in (Figure-1).

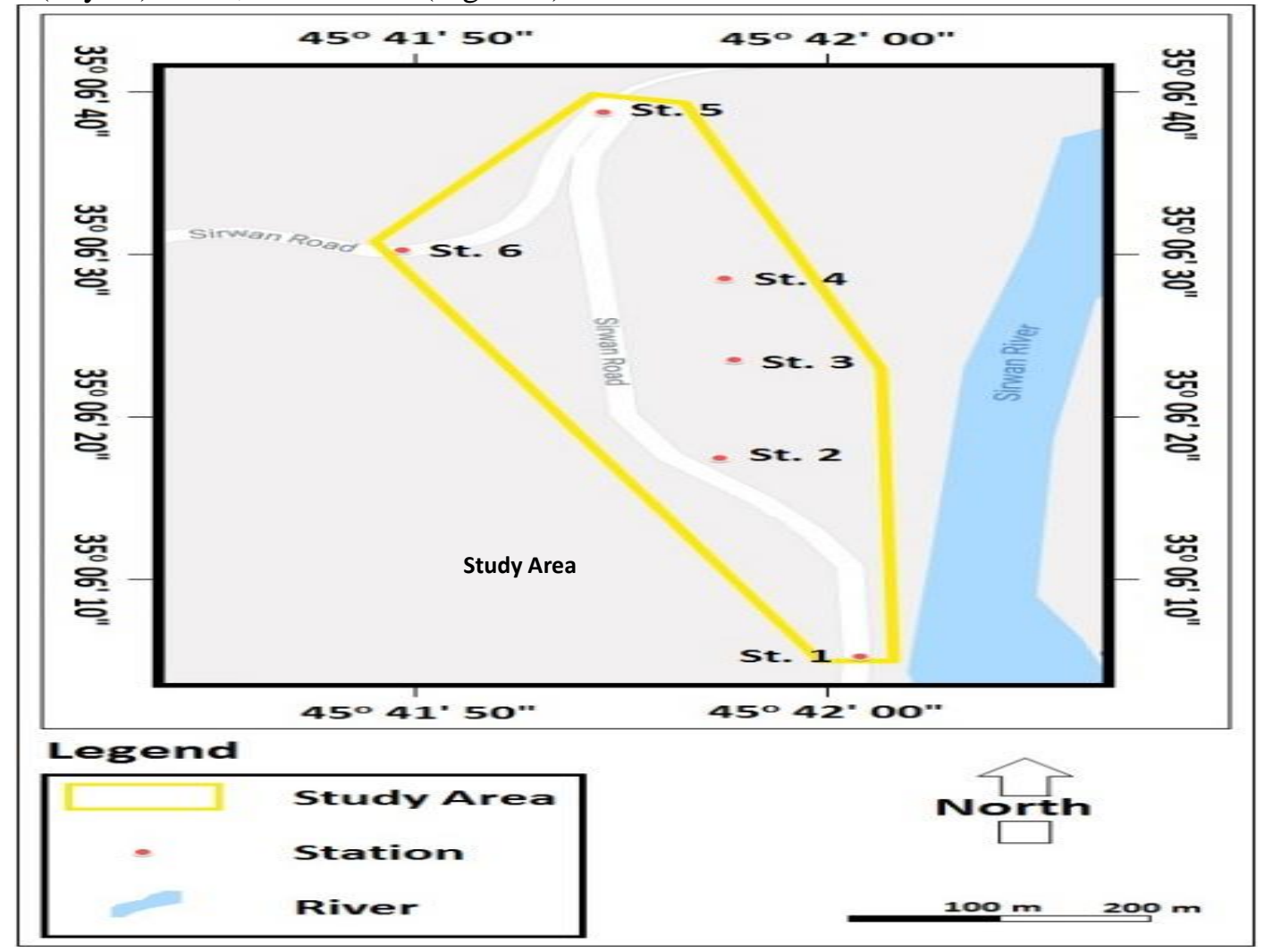

Figure 1-Location map of the study area 


\section{3. stratigraphy of the study area:}

In the studied station two formations were exposed PilaSpi Formation (Middle - Upper Eocene): which was found in stations (2,3, and 4), The upper part of this formation comprises well bedded, crystalline, limestone beds with chert nodules and chalky marl bands towards the top, whereas well bedded, porous, hard, limestone beds are found in the lower part of the formation [6], the other formation was Fatha (Lower Faris) Formation (Middle Miocene); which was found in stations (1, 5, \& 6), The upper part of the formation consists of alternating anhydrite, gypsum beds, interbedded with marl, and limestone beds, while the lower part comprises alternation of silty and thick claystone beds with thin bedded limestone and sandstone beds. [7] and [8].

\section{Tectonic and structure of the study area:}

The studied area is a part of Baranan mountain (anticline) which is located within the High Folded Zones near the boundary between low folded zone and high folded zones. [7]. Structurally, it is characterized by inclined layers with an average dip amount between $\left(29^{\circ}-38^{\circ}\right)$ of different directions ranging between $\left(128^{\circ}-290^{\circ}\right)$, with many sets of joints (orthogonal and conjugate) of various directions have been appeared.

\section{Geomorphology of the study area:}

From the geomorphological point of view, the most important features occur in the study area are; Breached anticlines, which are represented by erodible, soft sedimentary rocks of Kolosh and Gercus formations that were eroded forming valleys surrounded by hard limestone of the Pila Spi formation. The other landforms found are the Homoclinal (Strike) ridges which are formed as a result of folding and down cutting of rocks of less resistance. [9]

\section{Climate of the study area:}

The climate of the study area is characterized by heavy rain fall during the winter and especially in (January, February, and March) months, while it is very rare in Summer, as the annual precipitation rate reaches $(600 \mathrm{~mm})$, and the average monthly temperature of the area is $(4.80 \mathrm{c})$ recorded in January, as for the highest temperature was (32.6o c) as a monthly average recorded during July. [10]

\section{Analysis of structural factors on rock slope stability:}

In this study, six sites (stations) were chosen in which different failure types exist, in order to assess the structural factors (Joints) affecting the slope stability in the area. The unconfined compressive strength of the rock layers in the failure sites was indirectly measured by (point load test).

The inclination of slopes and the dip of beds and joints are defined by two numbers representing the direction (to the left) and the amount (to the right). Field observation showed that the slopes in the study area have many failures specially the rock fall, and toppling. All failures have been classified according to the classifications of [2].

The rock masses were also described by engineering terms, and some symbols were used to represent the data on the stereogram, these symbols are based on [3]

\section{Fractures and Slope Stability Assessment in the Stations:}

a- Station 1: This station is located at latitude $\left(35^{\circ} 06^{\prime} 08^{\prime \prime} \mathrm{N}\right)$ and longitude $\left(45^{\circ} 42^{\prime} 02^{\prime \prime} \mathrm{E}\right)$, within Fatha Fn., the slope at this station is $(30 \mathrm{~m})$ high, its length with its trend is $(107 \mathrm{~m})$, and its inclination is $\left(078 / 58^{\circ}\right)$, the average bedding plane attitude is $\left(128 / 30^{\circ}\right)$, as shown in (Figure-2), so that the slope is an oblique lateral $\left(\mathrm{d}=30^{\circ}\right)$, left lateral, and discordant.

The exposed rocks composed of green, gray, and reddish brown, fine to very fine grained, laminated to very thickly bedded $(1 \mathrm{~cm}-2.5 \mathrm{~m})$, very closely to widely spaced joints $(2 \mathrm{~cm}-2 \mathrm{~m})$, moderately weathered, slightly to highly permeable, and extremely strong $\left(\sigma_{\mathrm{c}}=242.2 \mathrm{MPa}\right)$, MARLY LIMESTONE.

The rocks are cut with four sets of joints (hko > b, hkl, hol >c, and okl >c) as shown in plate 1, the (hko $>$ b) set has an average dip $\left(346 / 53^{\circ}\right)$, spacing range $(2 \mathrm{~cm}-1.5 \mathrm{~m})$, and the persistence range $(10$ $\mathrm{cm}-2 \mathrm{~m})$, the (hkl) set of joints has an average dip of $\left(110 / 62^{\circ}\right)$, spacing range $(30 \mathrm{~cm}-2 \mathrm{~m})$ and persistence range $(5 \mathrm{~cm}-3 \mathrm{~m})$, the average attitude of joints in (hol >c) set is $\left(140 / 86^{\circ}\right)$ with spacing range $(5 \mathrm{~cm}-20 \mathrm{~cm})$ and the range of persistence $(7 \mathrm{~cm}-50 \mathrm{~cm})$, while the average attitude of $(\mathrm{okl}>$ c) set is $\left(062 / 60^{\circ}\right)$, range of spacing between joints $(10 \mathrm{~cm}-40 \mathrm{~cm})$ and range persistence $(10 \mathrm{~cm}-1$ $\mathrm{m})$.

The failure of rocks occurs by rock fall and toppling, due to the presence of (hko > b and hkl) sets which act as back to lateral release surfaces, with (hol >c) set which behaves as lateral release surface, 
and the work of the $(\mathrm{okl}>\mathrm{c})$ set as back release surface, and also that rock fall is likely to occur in the future due to the same reason

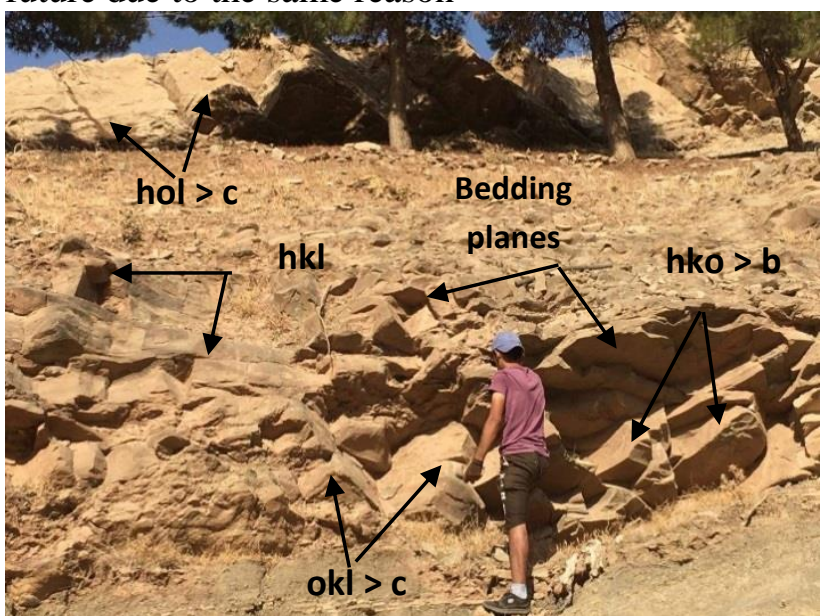

Plate 1-Joints and bedding planes in station 1

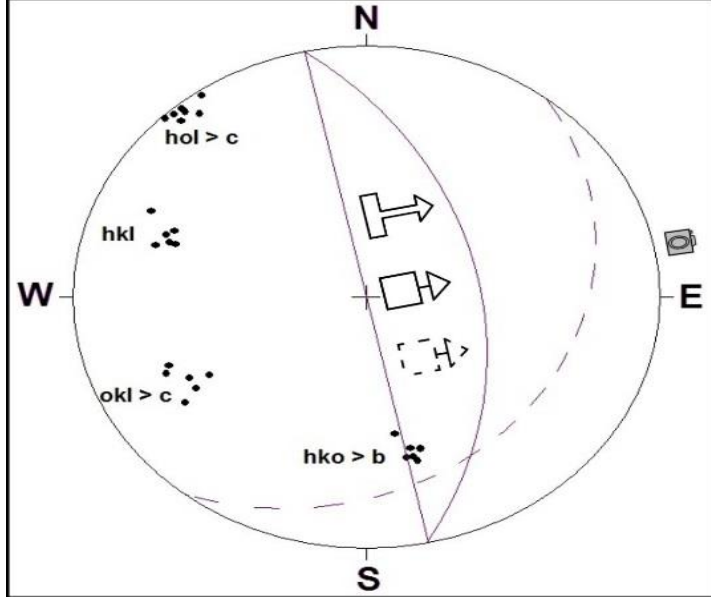

Figure 2-Stereogram shows relationship between discontinuities, slope and types of occurred and probable failures for station 1

Station 2: It lies about $(360 \mathrm{~m})$ to the northwest of station 1, and is located at latitude $\left(35^{\circ} 06^{\prime} 20^{\prime \prime} \mathrm{N}\right)$ and longitude ( $45^{\circ} 42^{\prime} 59^{\prime \prime} \mathrm{E}$ ), within Pila Spi Fn., the slope at this station is (64 m) high, the length is about $(130 \mathrm{~m})$ with its trend, its inclination is $\left(222 / 52^{\circ}\right)$, and the beds dip at an average attitude $\left(232 / 30^{\circ}\right)$, as in (Figure-3), so that the slope is a parallel $\left(\mathrm{d}=2^{\circ}\right)$, right lateral, and concordant.

The exposed rocks composed of white, light grey, and light brown, very fine grained, very thinly to thickly bedded $(5 \mathrm{~cm}-1.95 \mathrm{~m})$, closely spaced to widely spaced joints $(10 \mathrm{~cm}-1 \mathrm{~m})$, moderately to highly weathered, slightly to highly permeable, and very strong $\left(\sigma_{c}=145.68 \mathrm{MPa}\right)$, LIMESTONE, as in (Plate 2).

The rocks are cut with four sets of joints $\left(\mathrm{bc}, \mathrm{hkl}_{1}, \mathrm{hkl}_{2}\right.$, and hko > a) of various structural orientations, average attitude of (bc) set is $\left(059 / 50^{\circ}\right)$, average spaces between joints of $(20 \mathrm{~cm}-80$ $\mathrm{cm})$ and their lengths average $(30 \mathrm{~cm}-6 \mathrm{~m})$, whereas in $\left(\mathrm{hkl}_{1}\right)$ set, the average dip is $\left(162 / 80^{\circ}\right)$, the joints have spacing range $(20 \mathrm{~cm}-1 \mathrm{~m})$, and persistence range $(30 \mathrm{~cm}-2 \mathrm{~m}),\left(\mathrm{hkl}_{2}\right)$ set, in turn, has joints with an average attitude $\left(127 / 22^{\circ}\right)$, spacing range $(13 \mathrm{~cm}-20 \mathrm{~cm})$, and persistence range $(2 \mathrm{~m}-$ $6 \mathrm{~m})$, and the joints in (hko > a) dip at an average attitude $\left(342 / 81^{\circ}\right)$, with spacing range $(10 \mathrm{~cm}-1$ $\mathrm{m})$, and persistence range $(20 \mathrm{~cm}-80 \mathrm{~cm})$.

Three main rock failures' types have occurred and are likely to take place in the future; rock fall and toppling occurred due to the behave of (bc) set as back release surface, and $\left(\mathrm{hkl}_{1}\right)$ set with (hko > a) set as lateral release surfaces, sliding was also happened, like the joints in $\left(\mathrm{hkl}_{2}\right)$ set to act as basal surfaces, the same reason leads to the expectation that the same types of failure are likely to occur in the future.

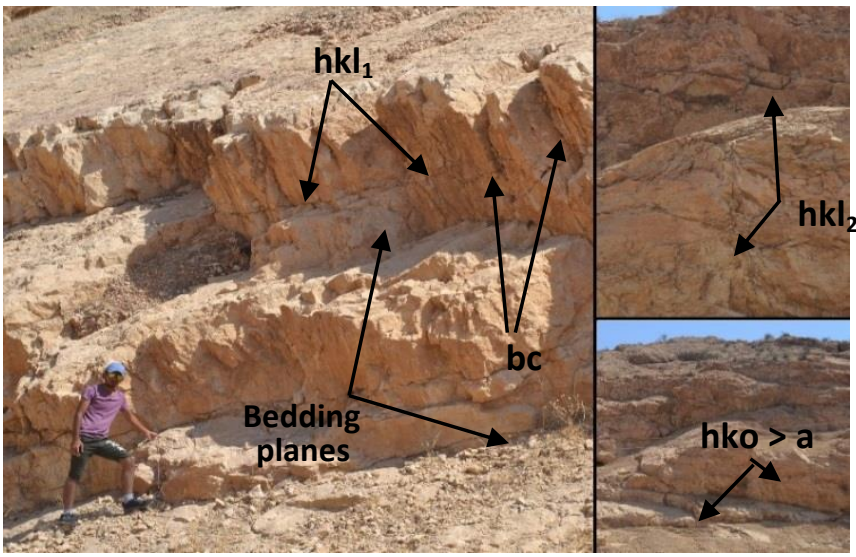

Plate 2-Joints and bedding planes in station 2

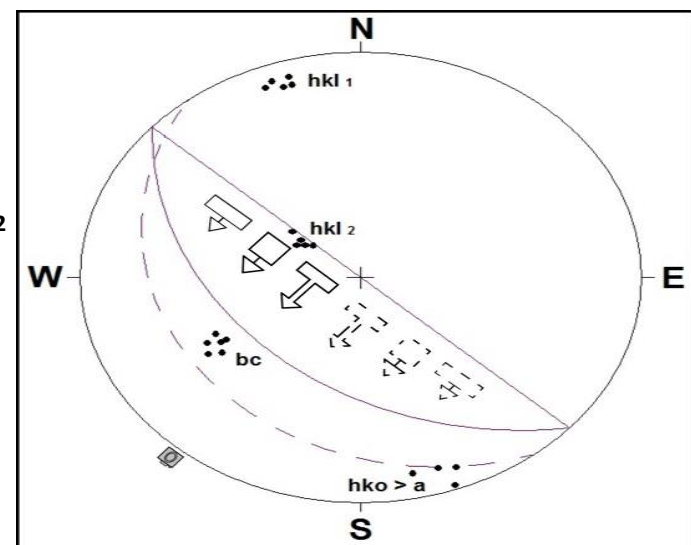

Figure 3-Stereogram shows relationship between discontinuities, slope and types of occurred and probable failures for station 2 
b- Station 3: this station lies about $(165 \mathrm{~m})$ to the north of station 2 , and is located at latitude $\left(35^{\circ} 06^{\prime}\right.$ $\left.25^{\prime \prime} \mathrm{N}\right)$ and longitude ( $45^{\circ} 41^{\prime} 59^{\prime \prime}$ E), within Pila Spi Fn., the slope at this station consists of 2 parts; general (first) slope which is $(12 \mathrm{~m})$ high, and its length with its trend is $(40 \mathrm{~m})$, with inclination $\left(290 / 48^{\circ}\right)$, the slope changes to the left forming side (second) slope that is $(10 \mathrm{~m})$ high, and its length with its trend is $(23 \mathrm{~m})$, with inclination $\left(150 / 90^{\circ}-\mathrm{OH}\right)$, and the bedding attitude is $\left(262 / 29^{\circ}\right)$ as in (Figure-4).

The exposed rocks composed of light grey and brown, very fine grained, thinly to thickly bedded $(10 \mathrm{~cm}-1.14 \mathrm{~m})$, extremely closely to very widely spaced joints $(1 \mathrm{~cm}-2.5 \mathrm{~m})$, moderately to highly weathered, slightly to highly permeable, and very strong (144.88 MPa), LIMESTONE rocks, as in (Plate 3), so that, the general slope is classified as an oblique lateral slope $\left(\mathrm{d}=62^{\circ}\right)$, right lateral, and concordant.

The rocks are cut with four sets of joints of various structural directions (ac, hkl, okl > b, and okl > c), the (ac) set has average attitude $\left(171 / 85^{\circ}\right)$, spacing range $(2 \mathrm{~cm}-2.5 \mathrm{~m})$, and persistence range of $(8 \mathrm{~cm}-3 \mathrm{~m})$, while the joints in (hkl) have average attitude $\left(122 / 37^{\circ}\right)$, spacing range $(1 \mathrm{~cm}-50 \mathrm{~cm})$ and persistence range $(25 \mathrm{~cm}-1.2 \mathrm{~m})$, average attitude of the joints in (okl $>\mathrm{b})$ set is $\left(217 / 34^{\circ}\right)$, the range of spacing $(5 \mathrm{~cm}-2 \mathrm{~m})$, with persistence range $(70 \mathrm{~cm}-3 \mathrm{~m})$, and the (okl $>\mathrm{c})$ set has an average attitude $\left(341 / 80^{\circ}\right)$, spacing range $(1 \mathrm{~m}-1.5 \mathrm{~m})$, and persistence range between $(80 \mathrm{~cm}-2 \mathrm{~m})$.

Failure occurred in the form of rock fall, due to the fact that the joints in (ac) set act as back release surfaces, and joints in $(\mathrm{okl}>\mathrm{c})$ set behave as lateral release surfaces.

Rock fall is expected to occur in the future due to the presence of overhanging rock mass in the side slope, as well as the behave of joint sets mentioned above, it is also likely to expect sliding as the joints in (okl > b) set act as basal surface, and also the bedding plane situation that encourages the sliding in some rock blocks.
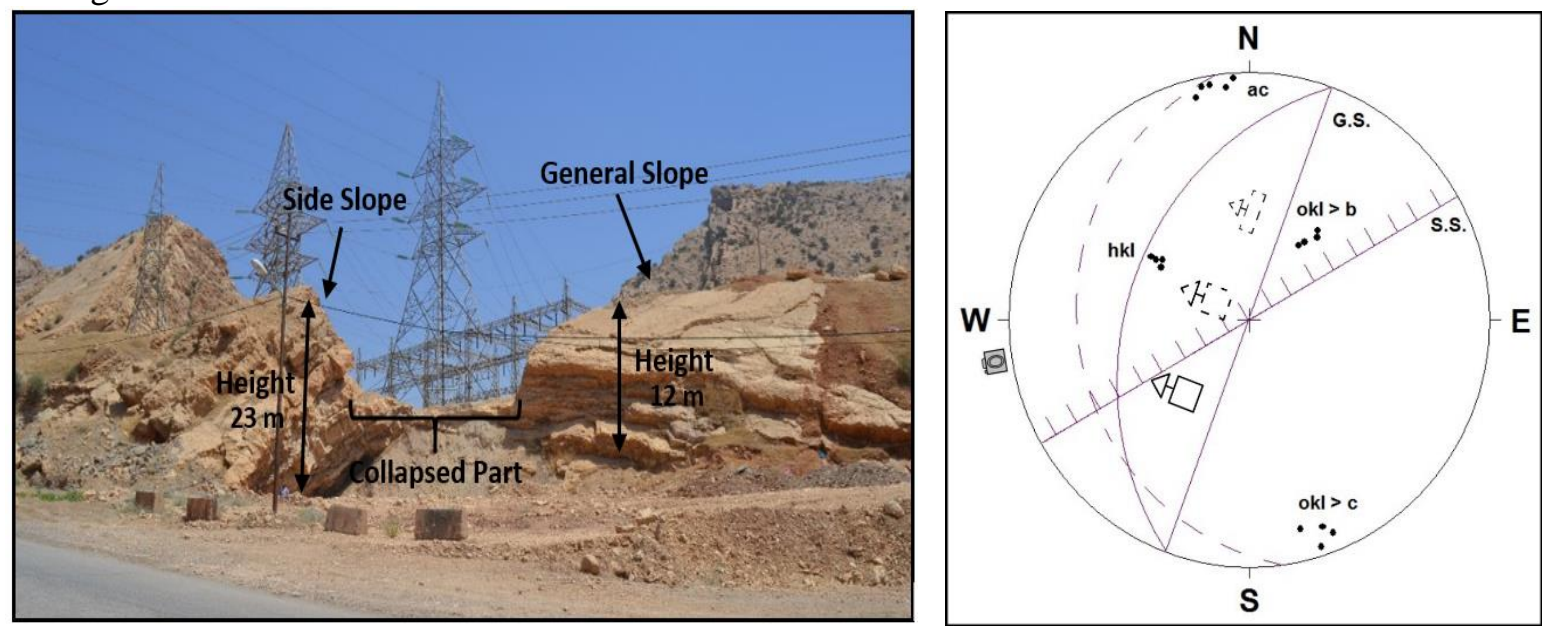

Plate 3-Joints and bedding plane in station 3

Figure 4-Stereogram shows relationship

between discontinuities, slope and types of occurred and probable failures for station 3

c- Station 4: This station lies about $(145 \mathrm{~m})$ to the north of the previous station, and is located at latitude ( $35^{\circ} 06^{\prime} 29^{\prime \prime} \mathrm{N}$ ) and longitude ( $45^{\circ} 41^{\prime} 59^{\prime \prime}$ E), within Pila Spi Fn., the slope at this station consists of general (first) slope which is $(88 \mathrm{~m})$ high, and its length with its trend is $(117 \mathrm{~m})$, with inclination $\left(190 / 55^{\circ}\right)$, and side (second) slope that is $(85 \mathrm{~m}) \mathrm{high}$, and its length with its trend is $(80$ $\mathrm{m}$ ), with inclination $\left(268 / 72^{\circ}\right)$, and the average bedding plane attitude is $\left(248 / 38^{\circ}\right)$, as in (Figure-5), so that, the general slope is an oblique lateral $\left(\mathrm{d}=58^{\circ}\right)$, left lateral, and concordant.

The exposed rocks composed of light to dark brown, very fine grained, thinly to very thickly bedded $(15 \mathrm{~cm}-2.2 \mathrm{~m})$, very closely spaced to widely spaced joints $(2 \mathrm{~cm}-2 \mathrm{~m})$, moderately to highly weathered, and very highly weathered in some areas, slightly permeable to highly permeable in some areas, extremely strong $(\sigma c=216 \mathrm{MPa})$, LIMESTONE, as in (Plate 4).

The layering at this station is cut with two sets of joints (hko $>a$, and hol $>a$ ); the average attitude of joints in (hko > a) is $\left(154 / 74^{\circ}\right)$, the spacing range is $(20 \mathrm{~cm}-1.5 \mathrm{~m})$, with persistence range $(30 \mathrm{~cm}$ 
$-7 \mathrm{~m})$, whereas joints in (hol > a) set have an average attitude $\left(070 / 41^{\circ}\right)$, spacing range between $(2 \mathrm{~cm}$ $-2 \mathrm{~m})$, and their persistence range between $(10 \mathrm{~cm}-2 \mathrm{~m})$.

The rock fall was occurred in the station, as the joints in (hko > a) set acts as lateral release surfaces, and joints in (hol > a) set act as back release surface, the same reasons make the rock fall as probable failure in this station, also the situation of the bedding planes leads to the expectation of sliding occurrence in the future.

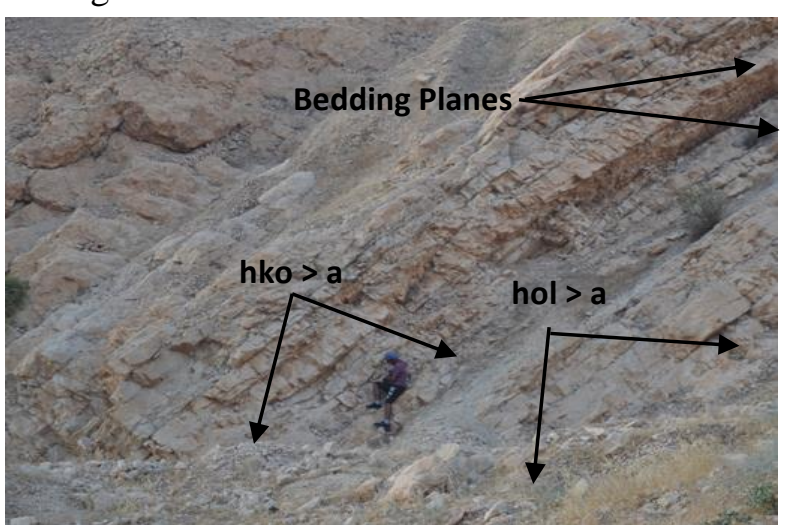

Plate 4-Discontinuities in station no. 4

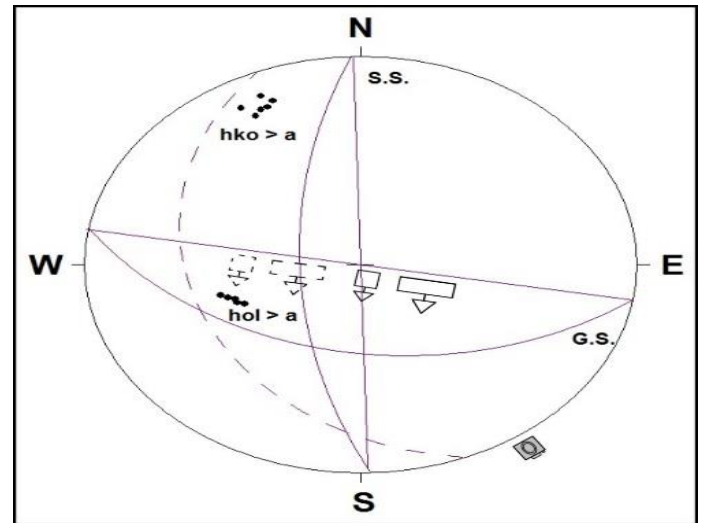

Figure 5-Stereogram shows relationship between discontinuities, slope and types of occurred and probable failures for station 4

d- Station no. 5: It lies about $(300 \mathrm{~m})$ to the northwest of station 4 , and is located at latitude $\left(35^{\circ} 06^{\prime}\right.$ $39^{\prime \prime} \mathrm{N}$ ) and longitude ( $45^{\circ} 41^{\prime} 55^{\prime \prime} \mathrm{E}$ ), within Fatha Fn., the slope at this station is (65 m) high, and the length with its trend is $(126 \mathrm{~m})$, with inclination $\left(123 / 52^{\circ}\right)$, and bedding dips at an attitude $\left(290 / 36^{\circ}\right)$, as in (Figure-6), so the slope is a parallel slope $\left(\mathrm{d}=14^{\circ}\right)$, left lateral, and discordant

The exposed rocks composed of gray and reddish brown, fine to very fine grained, medium to thickly bedded $(30 \mathrm{~cm}-2 \mathrm{~m})$, very closely spaced to widely spaced joints $(3 \mathrm{~cm}-1 \mathrm{~m})$, moderately to highly weathered, slightly to highly permeable, and extremely strong (239.8 MPa), MARLY LIMESTONE, as in (Plate 5).

The rocks in this station are cut with two sets of joints (hko $>a$, and hko $>b$ ); the first has an average attitude $\left(056 / 58^{\circ}\right)$, spacing range $(3 \mathrm{~cm}-80 \mathrm{~cm})$, and persistence range $(12 \mathrm{~cm}-2 \mathrm{~m})$, while the second has average attitude $\left(144 / 53^{\circ}\right)$, and the persistence range $(10 \mathrm{~cm}-1.2 \mathrm{~m})$ with spacing range between $(20 \mathrm{~cm}-1 \mathrm{~m})$.

Rock fall and toppling occurred in the station and are also likely to take place in the future as the joints in (hko > a) set and act as back release surfaces, and (hko $>$ b) set behaves as lateral release surface.

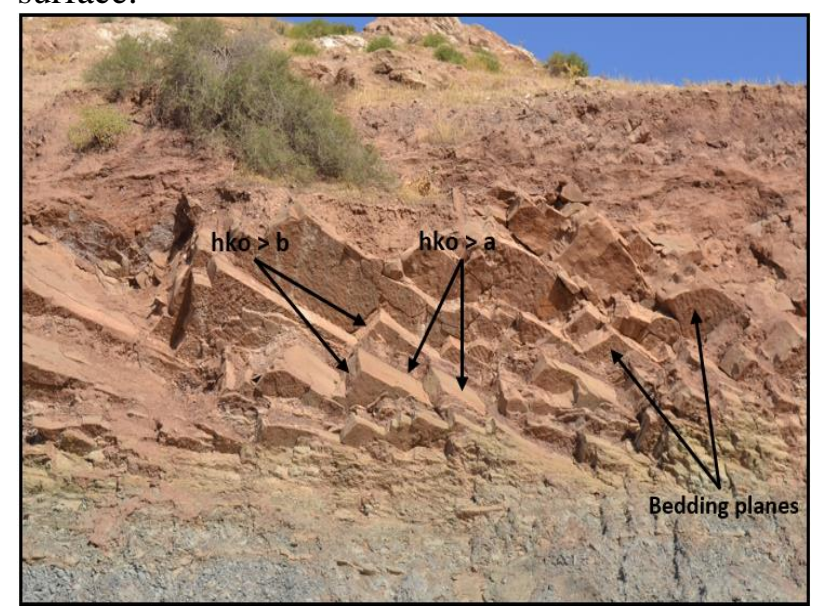

Plate 5-Joints and bedding plane in station 5

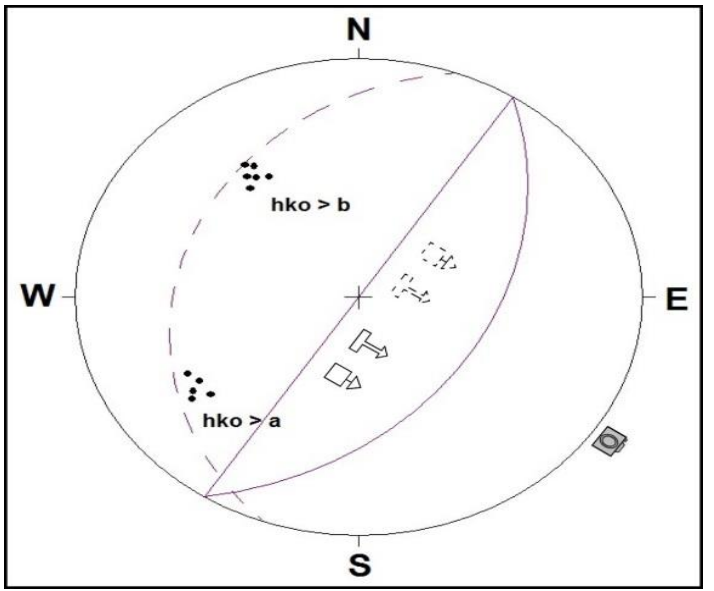

Figure 6-Stereogram shows relationship between discontinuities, slope and types of occurred and probable failures for station 5 
e- Station 6: This station lies about $(275 \mathrm{~m})$ to the southwest of the previous station, and is located at latitude $\left(35^{\circ} 06^{\prime} 31^{\prime \prime} \mathrm{N}\right)$ and longitude $\left(45^{\circ} 41^{\prime} 50^{\prime \prime} \mathrm{E}\right)$, within Fatha Fn., the slope at this station consists of general slope (first slope) which is about $(20 \mathrm{~m})$ high, its length with its trend is $(72.7 \mathrm{~m})$, and its inclination is $\left(178 / 58^{\circ}\right)$, and side slope (second slope) that is $(18 \mathrm{~m}) \mathrm{high}$, its length with its trend is $(22.5 \mathrm{~m})$, with inclination $\left(128 / 90^{\circ}-\mathrm{OH}\right)$, and bedding plane attitude is $\left(282 / 38^{\circ}\right)$, as in (Figure7 ), so that, the general slope is a orthogonal $\left(\mathrm{d}=76^{\circ}\right)$, left lateral, and discordant.

The exposed rocks composed of grey to reddish brown, fine to very fine grained with the presence of coarse sandstone in some parts, thinly to very thickly bedded $(10 \mathrm{~cm}-4.5 \mathrm{~m})$, very closely spaced to very widely spaced joints $(5 \mathrm{~cm}-3 \mathrm{~m})$, highly weathered to completely weathered at some parts, slightly permeable to highly permeable in some areas, strong $(\sigma \mathrm{c}=96 \mathrm{MPa})$, MARLY LIMESTONE, as shown in (Plate 6).

The rocks are cut with two sets of joints of different structural orientations (hko > b, and hol >a), the first has an average attitude $\left(144 / 52^{\circ}\right)$, spacing range $(5 \mathrm{~cm}-40 \mathrm{~cm})$, and persistence range $(20 \mathrm{~cm}$ $-2 \mathrm{~m})$, while the second set of joints has an average attitude $\left(044 / 50^{\circ}\right)$, and the joints persistence range between $(10 \mathrm{~cm}-1 \mathrm{~m})$ with spacing range between $(20 \mathrm{~cm}-3 \mathrm{~m})$.

As the joints in (hko > b) set serve as lateral release surface, and (hol > a) set joints act as back release surfaces, rock fall took place in this station, the behaves of the joint sets, as well as, the bedding planes situation in the station makes it favorable that rock failures expected in this station to occur in the future in the form of fall and sliding.
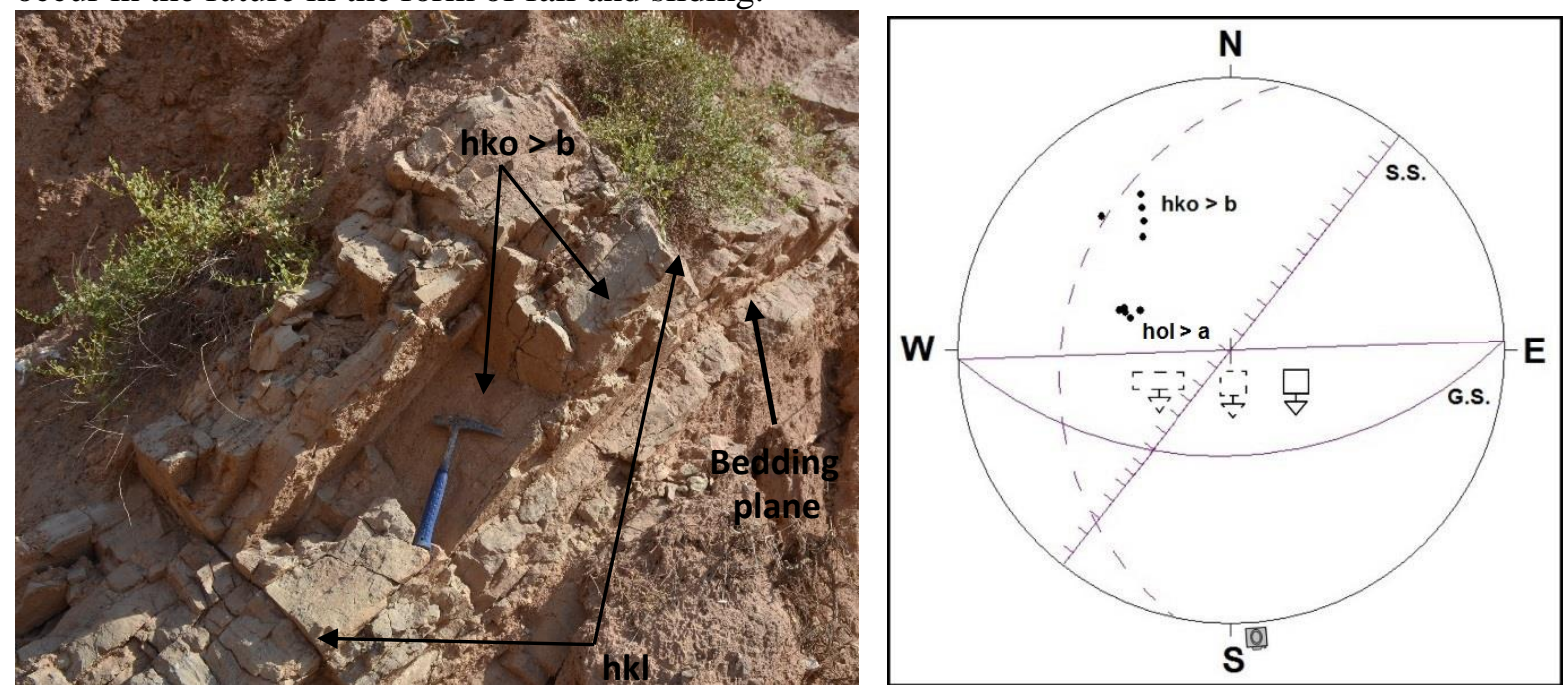

Plate 6-Joints and bedding planes in station 6

Figure 7-Stereogram shows relationship

between discontinuities, slope, and types

of occurred and probable failures for station 6

\section{Conclusion}

a- Most of the failures in the study area take place due to the presence of rock masses surrounded by discontinuities from all directions, as the weathering and differential erosion processes affect the slopes, and also due to the cut of slope toes as a result of road construction in the study area.

b- The discontinuities (joints and bedding planes) in the rock masses play various roles during different failure types according to their nature; back release surfaces (BRS), lateral release surfaces (LRS), or basal surfaces (BS).

c- Different types of rock failure occurred in the study area including Rock fall, sliding, and toppling, and the ratios of these failure are; $60 \%$ rock fall, $30 \%$ toppling, and $10 \%$ sliding.

\section{Recommendations}

a- Removal of the unstable blocks which are liable to fail in the critical cases, as in stations 2 and 6.

b- casing the slopes with covenant materials such as concrete (as in site 4) and gabions (as in sites 2 and 6), construction of retaining walls and digging of protective trenches to protect the slopes and reduce the hazard, as in stations 1,3 , and 5, as well as using warning signs along hazardous locations that are prone to collapse to attract the attention of pedestrians to the riskiness of the place. 


\section{Acknowledgments}

Thanks for Dr. Janan Mansour for helping with (GEOrient 9.5.0.) software, and my colleague Aya Ali for helping in the field work and collecting the rock samples.

\section{References}

1. Blyth, F.G.H and De Freitas, M.H.1984. AGeology for Engineers, 7th ed. Edward Arnold. London. $325 \mathrm{p}$.

2. Hoek, E. and Bray, J. W. 1981. Rock Slope Engineering Inst. of Mining and Metallurgy. London. $358 \mathrm{p}$.

3. Al-Saadi, S.N. 1981. A Method for Mapping Unstable Slopes with Reference to the Coast line of S.W. Dyfed, Wales, Unpub. PhD. Thesis, University of Bristol, 252 p.

4. Anon, 1972. The Preparation of Maps and Plans in Terms of Engineering Geology, Quarterly Jour. of Eng. Geo., 5: 293-382.

5. Hawkins, A.B. 1986. Rock Description and Classification for Engineering purposes. Geo. Soc. Eng. Geo. Special publication. 2. 1186 p.

6. Bellen, R.C., Dunnington, H.Y., Wetzel. and Norton, D. N. 1959. Lexique Stratigraphique International, V.III, Fasc. 10a, Asia, Iraq, 333 p.

7. Buday, R.T.1980. The Regional Geology of Iraq. Kassab, I.I.M and Jassim, S.Z., V.1. Stratigraphy and Paleogeography. D.G Geo. Surv. Min. Invest. (SOM), Baghdad. 445 p.

8. Jassim, S. Z. and Goff, J. C. 2006. Geology of Iraq. 1st edition, printed in Czech Republic. 341p.

9. Salar, S.G. 2017. Urban Geomorphology of Darbandikhan District Using GIS and RS Iraqi Kurdistan region, Journal of Garmin University, Vol.4, Special Issue; ICBS Conference, PP. 301319.

10. Climatological Atlas of Iraq, 1989. Iraqi General Air Conditioning Authority, 145 p. 